Archived version from NCDOCKS Institutional Repository http://libres.uncg.edu/ir/asu/

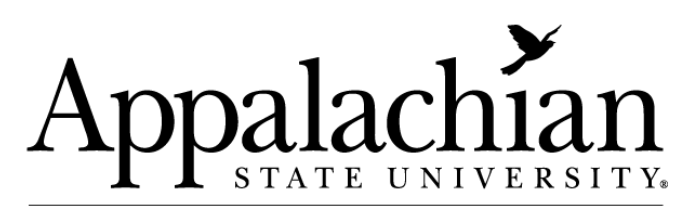

B O O N E, NORTH CAROLI N A

del Carmen, Alejandro, and Matthew B.

Robinson (2000). Crime prevention

through environmental design and

consumption control in the United States,

Howard Journal of Criminal Justice 39, 3:

267-289. 


\title{
Crime Prevention Through Environmental Design and Consumption Control in the U nited States
}

\author{
ALEJANDRO DEL CARMEN AND MATTHEW B. ROBINSON \\ A lejandro del Carmen is Assistant Professor of Crimin ology and Criminal \\ Justice, University of Texas at Arlington, USA; M atthew Robinson is Assistant \\ Professor of Criminal Justice, Appalachian State University, USA
}

\begin{abstract}
CPTED theory, research and practice are frequently held to be relatively recent developments in the field of American criminology, generated largely by the works of Oscar N ewman (1972) and C. Ray Jeffery (1971). This view of CPTED and its development in the United States falls short of providing an adequate understanding of the vital part that it has played, and can play, in theadvan cement of crime prevention theory and public policy. CPTED is actually broader than as it is currently understood in the discipline of criminology. This is demonstrated through an examination of the 'era of consumption' (that is, the time period roughly from the early 1800 s to early 1900 s where the disease later referred to as tuberculosis was widespread in the US); during this time period, efforts to control the spread of illness were achieved through CPTED strategies which preceded the academic writings of those considered to be the founders of CPTED. Our main goal is to increase the understanding of and appreciation for the vital role that CPTED has played in the history of crime prevention in the United States. Finally, implications are discussed for the prevention of tuberculosis today, as well as HIV infection and AIDS.
\end{abstract}

Throughout academic criminology, the concept of 'crime prevention through environmental design' (CPTED) is generally understood as a manipulation of things and conditions surrounding people and property which influences the selection of targets by motivated criminal offenders, in order to reduce or eliminate the probability of criminal offences (Brantingham and Faust 1976). CPTED is the 'specific management, design, or manipulation of the immediate environment in which crimes occur in a systematic and permanent way' (Bennett and Wright 1984, p. 25). It is focused on the 'settings in which crimes occur and on techniques for reducing vulnerability of the settings' (Taylor and Harrell 1996, p. 1), because its central premise is that crime can be facilitated or inhibited by features of the physical environment (Clarke 1995).

While CPTED generally involves changing the environment to reduce the opportunity for crime, other goals include reducing fear of crime and 
perceptions of crime risk, increasing the aesthetic quality of an environment by reducing conditions of incivilities for example, and increasing the quality of life for law-abiding citizens, especially by reducing the propensity of the physical environment to support criminal behaviour (Clarke 1995; Crowe 1991; Robinson 1999).

CPTED theory, research, and practice are frequently held to be relatively recent developments in the field of American criminology, generated largely by the works of O scar Newman (1972) and C. Ray Jeffery (1971). This view of CPTED and its development in the United States falls short of providing an adequate understanding of the vital part that it has played, and can play, in the advancement of crime prevention theory and public policy.

CPTED is actually broader than as it is currently understood in the discipline of criminology. We demonstrate this through an examination of the 'era of consumption' (that is, the time period roughly from the early 1800 s to the early 1900 s where the disease later referred to as tuberculosis was widespread in the US). During this time period, efforts to control the spread of illness were achieved through CPTED strategies which preceded the academic writings of those considered to be the founders of CPTED. Essentially, CPTED measures were developed and utilised with the interrelated goals of preventing the spread of both tuberculosis and criminal behaviour. When efforts were aimed at preventing only one of these 'social ills', the other problem was inevitably alleviated, as well, owing to the fact that both conditions stemmed from the same factors. By broadening the scope of CPTED beyond its current standing, we seek to increase the understanding of, and appreciation for, the vital role that CPTED has played in the history of crime prevention in the U nited States.

\section{Crime Prevention and Consumption Control: A Broader Approach to CPTED}

The efficacy of crime prevention programmes rests on adequately understanding the complexity of criminal behaviour ( Lab 1997). Criminal behaviour occurs when various factors interact in a given environment in time and space. The concept of interaction means 'where a relationship of deterministic influence between two or more variables cannot be resolved into simple functions of one (or several), but instead must be treated as a joint function of all, as an integrated system of mutual or reciprocal influences' (McCall and Simmons 1966, p. 16).

Interactive or integrated explanations of criminal behaviour start out with a search for factors which affect one another in such a way that the behaviour results. Given that factors which produce criminal behaviour may also produce other outcomes, efforts to alleviate crime may also prevent those other outcomes. At the same time, efforts aimed at preventing those other outcomes may also prevent criminal behaviour. The argument made in this article is that efforts aimed at preventing crime during the era of consumption were to a degree also aimed at controlling and preventing the spread of consumption (that is, tuberculosis), and vice versa. We demonstrate that efforts of the health and criminal justice systems in the 
United States were combined to achieve prevention of consumption and crime. These efforts included: recommendations from medical doctors and nurses; educational campaigns aimed at promoting lifestyle changes of infected and potentially infected individuals; travel and relocation efforts; altering inner-city conditions (for example, poverty, unemployment, tenement housing); and incarceration. Such efforts were sometimes aimed only at preventing either consumption or crime, but inevitably they helped alleviate both conditions. While we do not assert that these efforts paint a complete picture of consumption/ crime prevention efforts during the era of consumption, they are representative of an interactive approach to prevent the spread of both consumption and crime; and they demonstrate that CPTED has been in practice for longer than it is currently given credit for in the discipline of criminology.

\section{Consumption: What is it?}

Throughout most of the 18th century, the disease presently known as tuberculosis was commonly referred to as consumption. Consumption has been an important issue at the national level since the early 1800 s due to its deadly effects. At the time, consumption was responsible for one in every five deaths in the United States (Rothman 1994).

As medical science has progressed, our understanding of tuberculosis has become more complete than it was in the early 1800 s. N ow we can accurately describe its general symptoms, which can include feeling weak or sick, weight loss, fever, night sweats, coughing, chest pain, and coughing up blood. We can also accurately describe how the disease is spread and therefore can prevent it much more effectively than we could in the early 1800s. For example, now we know that tuberculosis is spread from person to person through the air; the disease usually affects the lungs but can also invade other parts of the body (Watauga Democrat 1999).

Most people exposed to tuberculosis germs will not become infected unless they are exposed for a long period of time (usually months) to air with a high concentration of tuberculosis germs. People at highest risk for developing tuberculosis include individuals who share the same breathing space with someone who has tuberculosis (for example, family members, friends, co-workers), people living in conditions of poverty, homeless people, foreign-born citizens from countries with high concentrations of tuberculosis, nursing home residents, prisoners, alcoholics and intravenous drug users, people with certain medical conditions such as diabetes and certain types of cancers, and people who are underweight and infected with HIV (Watauga Democrat 1999).

Ironically, the disease is currently on the increase in the United States partly because of complacency which led to a lack of funding for preventing tuberculosis in the 1980s. Today, there are over 22,000 cases of full-blown tuberculosis reported each year in the US, and an estimated ten to 15 million people infected with the germ that causes tuberculosis. Other conditions which have compounded the tuberculosis problem include social issues such as poverty, homelessness, substance abuse, a lack of access 
to medical care, and an increase in immigration from countries where tuberculosis is more widespread (Watauga Democrat 1999).

Given our greater understanding of tuberculosis today, we know that the germs which cause the disease do not live in sunlight and many can be killed through ultraviolet light. Preventing its spread can, therefore, be achieved through exposure to ultraviolet light and by avoiding conditions where tuberculosis germs thrive. The simplest prevention mechanism remains covering one's mouth when one coughs or sneezes (Watauga Democrat 1999). Although much of this medical knowledge was not known during the era of consumption, efforts to prevent its spread seem remarkably informed in retrospect.

\section{Relationships Between Consumption and Crime During the Era of Consumption}

During the era of consumption, despite the fact that not all criminals were viewed as being sick and not all sick were viewed as being criminals, there were strong associations made between these two groups. These associations, although not usually represented in the law, led to the notion that criminals and consumptives were to be treated alike.

During this time, causes of crime were generally thought to lie within particular segments of the urban population. For example, as secretary of the Children's Aid Society, Charles Brace wrote The Dangerous Classes of N ew York, in which he detailed the living conditions of 'German ragpickers, street rovers, the poor, the little Italian orphan grinders, homeless girls, the ignorant, the outcast street children, and the nineteenth street gang of ruffians' (Quinney 1970, p. 53). As suggested by the title of Brace's book, these people were viewed as threats to society.

Thoughts about the aetiology of crime varied over the era of consumption. For example, around the time of the Civil War, those who wrote about crime included Z. Brockway (Superintendent of the Elmira Reformatory), M. Cassidy (prison administrator), E.C. Wines (secretary of the Prison Association of New York), F. Sanborn (chairman of the Massachusetts Board of State Charities), and R. Vaux (lawyer, president of the Board of Inspectors of Eastern State Penitentiary, and former mayor of Philadelphia). Other writers affiliated with the National Prisons Reform Congress, National Conferences of Charities and Corrections, National Prison Congress, and Society for Alleviating the Miseries of Public Prisons also wrote about crime. According to Quinney (1970, pp. 52-3), these thinkers viewed crime as a "product of "disharmony" in the operation of social forces, "constituents", or institutions of society ...' including 'drinking, lack of trade education, desire for luxuries, poverty, oblivion of religious and moral principles, idleness, abnormal family relations, bad company ...'; therefore, crime was viewed as a disease which would spread throughout segments of society if such conditions in society were left untreated.

An early result of the overlapping views of criminals and the sick was that workers of organisations such as the National Prison Association and the Congress of Charities and Corrections saw themselves as doctors rather than 
guards. This image was popularised by the physicians domination of criminological research in the United States at the time (for example, Lombroso 1911). As such, therapeutic techniques were used in prisons and reformatories, considered to be effective preventive tools when dealing with 'sick' criminals. For instance, the First Report of The Board of State Commissioners (1871) included a statement to the effect that the criminal offender was 'pathological' and 'diseased'. Thus, it was believed that medical science provided the best possibilities for a preventive mechanism and a cure.

The association of crime with disease was once again made by The Second Report of State Commissioners (1871, p. 2): 'crime, like disease, was revealed in the face, the voice, the person, and the carriage'. It was also affirmed by this report that 'the improvement or deterioration of a criminal is as palpable as that of a lunatic'. A lunatic, at the time, was considered to be someone demented who was not able to function in society.

This association of crime with disease was also evident in the discussion regarding the proper treatments that would be most effective in preventing and curing societal ills. The Second Report of State Commissioners (1871) indicated that: 'if prison-keepers, as a class, had the education, the devotion, and the ability of medical superintendents, the principles which lie at the foundation of all rational treatment of crime, would be as well known and as certainly demonstrated, as those which underlie the treatment of insanity' (p. 3).

Francis Allen's concept of 'The Rehabilitative Ideal' presupposed that crime was a symptom of 'pathology' and that criminal offenders should be treated like sick patients. According to Platt (1966): 'the older a criminal, the more chronic was his sickness; similarly, his chances of recovery were less than those of a young person' (p. 13). In essence, then, people who contracted consumption and people who engaged in criminal behaviour were placed in the same social category, as undesirables. These unwanted persons were perceived as threats to the safety of American society. These two social ills were vigorously condemned by those advocating a strong social defence. Thus, the same CPTED techniques were used to prevent the spread of both consumption and criminal behaviour because these efforts to prevent consumption and crime were aimed at the same people and altered the environments which they shared.

\section{Prevention During the Era of Consumption}

Prior to the discovery of the germ responsible for causing consumption, a number of preventive environmental design techniques were in practice. Some of these strategies were the recommendations by doctors to consumptives to seek jobs close to the ocean, the promotion of travel to the west, and the construction of special facilities designed to house consumptive patients. Even though these techniques were implemented with the goal of preventing the spread of tuberculosis, they also prevented criminal activity as the external environment was permanently changed by their existence. 
Physicians based their therapies on an ancient tradition of humoral medicine which entailed the balancing of elements within the body while framing their interventions accordingly. It was commonly held that consumption had origins in irritations which were enhanced by the individual's internal condition interacting with the environment. This meant that whether or not there was a genetic predisposition for having the disease, environmental influences could serve to promote its development or prevent it from taking place.

This, however, must not be interpreted as suggesting that the role of heredity was unimportant in discussions pertaining to the causes of criminal behaviour in 19th century American society. To the contrary, the overall emphasis among officials was on an approach which was inclusive of both organism and environment. This approach was evident in a speech given by Professor Charles Henderson in 1899 at the National Conference of Charities and Correction. He stated that despite the fact causes of defect were linked to industry and government, 'it was important to acknowledge that these were also biological and remained deep in man's relation to nature'.

This emphasis on a preventive approach inclusive of biology and environmental factors was also evident in a speech made by Charles Cooley (1896, p. 4) to the National Conference of Charities and Correction. He stated that it was pointless to create a dichotomy between 'nature' and 'nurture' since 'like male and female, each is sterile without the other'. In addition, Cooley stated that 'the union of nature and nurture is not one of addition and mixture, but of growth, whereby the elements are altogether transformed into a new organic whole'. Such statements suggest that criminal behaviour was thought to be caused by numerous factors indicative of an underlying pathology. In support of this, Quinney (1970) wrote that most writers at the time 'assumed that the operation of any one factor could only partially explain the phenomenon of crime' (pp. 52-3).

At the same time, the dominant perspective also assumed that such behaviour could be effectively changed. O ne mechanism was education. For example, a general preventive technique implemented at the time was a public promotional campaign which advised people to live and work close to the ocean. Specifically, some potential consumptives, as determined by their assumed genetic predisposition, were strongly 'encouraged' by physicians to hold careers close to the ocean. The recommendations stemmed from the belief that the ocean breeze would alleviate respiratory problems. According to the main physician of the British Navy, Dr Thomas Trotter: 'a sea life has often been considered a preservative against pulmonary consumption, and a voyage in a ship frequently recommended as a cure for the complaint' (Lloyd 1965, p. 4). Such early suggestions are remarkably similar to those of today, as people with tuberculosis are advised not to live in crowded or congested conditions, and to be safely exposed to sunlight.

It is important to recognise that most people regarded a doctor's 'suggestion' almost as an order, which if not obeyed, would result in grave consequences, including death. Furthermore, it must also be noted that the advice to conduct a voyage was almost al ways given to those who could afford 
it. In contrast, the advice given to the poor was to seek a job close to the ocean. Interestingly, irrespective of one's socio-economic status, the idea of being close to the ocean was always the same even though the exact content of the advice varied depending upon the social class of the patient. Another physician with perhaps less interest in the sea than Trotter, shared his enthusiasm as he stated that 'sea voyaging in warm latitudes is conceived to be one of the most effective means in eradicating, or at least, keeping dormant the tuberculosis disposition' (Sweetser 1836, p. 6). He added that the disease 'is not commonly developed, even in the predisposed, during long voyages, and it is not frequent among sailors during their seafaring life'.

For the most part, physicians were not precise about the optimal length of the voyage. In some cases, one winter was sufficient, but in others, several years were necessary. For individuals who were 'at risk' of continuing the family tradition of dying of consumption, a strict diet and a regimen of outdoor exercise in a warm climate were recommended. The climate was of such importance that some physicians sought the study of climatology, in hopes of making a science of environmental preventive and treatment mechanisms.

The same technique to encourage exposure to the sea was used for criminal offenders and those considered to be potential criminals. For instance, owners of shipping firms had little concern about the criminal records of men they hired as sailors with the belief that life at sea would suppress criminal tendencies. Also, persons found guilty of having committed criminal offences were sentenced to serve time as sailors aboard ships (Rothman 1994).

Another preventive mechanism used at the time was the encouragement of people to move out of the populated cities of the east to the western region of the United States. It was believed that the western environment would prevent the development of consumption in those generally predisposed to carry the disease. It was also believed that such relocation would benefit those who already had the disease. However, the option to travel west was only available to those who could afford it.

Despite this, the dream of wealth and health was not limited to middle and upper class consumptives. Health and wealth was also the dream of those who saw illegal activities as the means to those goals. The gold rush of the mid-19th century held far more promise for quick wealth than the commission of street crimes in the east. Those who were viewed as undesirable in terms of criminal behaviour, were strongly 'encouraged' by authorities of the justice system to pursue their interests in the west. The extent that these techniques were effective in getting consumptives out of cities would also increase the efficacy of crime control efforts.

According to most physicians at the time, the journey was as important as the destination. The idea of travelling to the west by horseback became popular among potential patients. Numerous physicians, such as Sweetser (1836), often expressed their belief that 'long journeys ... are often of peculiar advantage to those strongly predisposed to consumption, and may likewise be useful in its incipient stage' (p. 7). 
Physicians who encouraged the sick to travel to the west were strongly influenced in their decision-making process by the interaction of other factors (for example, religion). According to Quinney (1970) 'Reformism from the beginning of the century, shaped by the Enlightenment of the eighteenth century, romanticism, humanitarianism, principles of democracy, and the religious idea of community, created an awareness of social problems ...' (p. 51), including crime and disease. For example, a strong religious fervor was evident as the image of a more loving and tender God replaced the more forbidden Calvinist deity (Rothman 1994). This religious awakening not only influenced physicians but also made a great impact on potential invalids as well. The thought of a tender God not only provided potential invalids comfort but also enabled some of them to turn a voyage for preventing illness into a spiritual journey (Cross 1958). Furthermore, the west was regarded as not only a place where illness was cured or prevented but also a region where spiritual growth was expected. Thus, in order to obey both their ministers and doctors, to serve body as well as soul, potential invalids and those who already suffered from consumption made themselves into penitent pilgrims in search of redemption (Miller 1956). These trips were viewed as religious in nature since they provided a unique opportunity for potential invalids to evangelise.

The trips to the west were also believed to provide relief to cities suffering from overcrowding at the time. According to Platt (1966), both the concentration of the population in the cities, and the lack of economic stability, were factors believed to have an impact on the potential of criminal activity. This was also accompanied by the threat of spreading consumption more rapidly. According to the penologist William Morrison (1897), a community of this sort:

produces a large proportion of weak and ineffective people possessing very inadequate physical equipment for successfully fighting the battle of life. As a result of their physical deficiencies people of this kind are unable to obtain regular employment or to keep in work when they obtain it. Disease and sickness interfere with them and incapacitate them, and they are driven down to the very lowest social stratum if they do not happen to have been born in it. ( $p .19)$

According to Platt (1966), the popular belief at the time was that 'a child entering such a social world is impelled by circumstance, by temptation, by paternal neglect, and by a sense of adventure into a life of crime' (p.13). Thus, the removal of individuals from these poverty and disease-stricken neighbourhoods represents an early attempt to implement a CPTED technique aimed at permanently changing the environment in order to reduce the number of potential or already diagnosed consumptives and criminals.

According to Rothman (1994), health seekers (potential consumptives and those already suffering from the disease) congregated in locations of the west that real estate developers, railroad agents, and physicians, promoted as being especially salubrious. The west received the greatest number of health seekers during the 1870s accounting for a big proportion of the population growth. 
Not all health seekers went west. Despite the large influx to this region, a large number of the poor health seekers that could not afford the cost of travel, took bed in one of the hospitals or facilities for 'poor consumptives'. These facilities, by virtue of the fact that they were designed to prevent the full development of genetically predisposed consumptives (some of whom were considered to be potential criminals), may be viewed as the first institutionalised crime prevention facilities created during this era. Their primary concern was not only to provide a safe refuge for the sick but to also modify the environments of those thought to be potential criminals and potential consumptives. Even though these facilities did not have signs at their front doors stating their preventive goals, their ultimate objective was to prevent individuals from becoming social undesirables by acquiring consumption and engaging in criminal behaviour. According to Rothman (1994), during the 1870s, health seekers could find beds on the wards of public hospitals and in homes for incurables such as The Chanming House in Boston and The Home of the Protestant Episcopal Mission in Philadelphia.

It was not until 1882 when Robert Koch identified the tubercle germ, that the attempts of health seekers to find a preventive environment in the west diminished. Koch's discovery revolutionised the medical and social history of consumption. Public health officials began to understand that tuberculosis was not genetic, but that it spread from person to person. The bacilli lodging in a cavity in the lungs was coughed up and then became airborne coming in contact with another person or landing on dust particles (Rothman 1994). Thus, the bacteria was thought to be spread through a kiss or a shared drink.

Upon this discovery, physicians embarked in an educational campaign with the aim of informing the public of measures they could take to prevent infection. The public was told that the best defence against contracting the disease was through the build up of strong immune resistance. This could be achieved through a healthy diet, getting plenty of fresh air, and keeping clean. In addition, those with the illness were told to follow strict hygiene and stop 'promiscuous spitting' (Prudden 1917).

Such educational campaigns assume certain things about human nature, including that an audience will be affected as they learn information they can use to alter their lives and protect themselves. It was during this same decade that Lombroso's theory of the 'born criminal' was challenged by theories of learned criminal behaviour (Jeffery 1990; Quinney 1970).

The association of crime with consumption continued even after the discovery of the tubercle bacteria. This association is evident in the belief that the same environmental technique aimed at preventing either the spread of consumption or criminal activity would assist in the prevention of the other, a belief that was discussed in a speech given by Mrs Clara Leonard, a delegate at a national health conference. Leonard (1879) stated that in order to prevent crime, 'communities should establish schools, kindergartens, and other preventive institutions in order to counteract the foul tenements and the dirty streets and al leys of our great cities' where 'the tainted air is sapping the vitality of the children, poisoning their blood, 
sowing their bodies with the seeds of disease, and educating the helpless hosts who crowd every market place of labor, unfit physically to contend in the struggle for existence' (p. 13).

The advice given to consumptives to live a different lifestyle came from all directions. For example, the advice of medical doctors prompted changes in the environment. O ne of the first doctors to engage in an active campaign against the tuberculosis virus was Herman Briggs, the director of the bacteriological laboratory of the New York City Department of Health. He assured the American public on several occasions that although preventive measures could not totally eliminate the spread of the disease, they would help to control it. Knopf, another known physician, reinforced Briggs's message. Knopf (1907) affirmed that people could reduce the threat of contagion if they would 'strive to be as much as possible in the open air, drink plenty of pure, clean water, keep early hours, live as regular a life as possible, avoid the saloon, and never take alcoholic beverages' ( $p .3)$.

While these recommendations were aimed at those considered to be 'at risk' of contracting tuberculosis, in order to promote the modification of their environments for the sake of reducing their exposure to the disease, avoidance of the saloon environment and drinking of alcoholic beverages was also being promoted in order to prevent criminal behaviour.

During the period of 1890 to 1920, public health officials initiated two different but interrelated approaches to reduce the perils of consumption. These included the improvement of social conditions that were thought to breed tuberculosis and the control of behaviour of infected individuals. Public health campaigns contributed to the belief that tuberculosis was the disease of the poor, particularly of the recently arrived immigrants who lived crowded together in the tenement house districts and who were believed to have a predisposition to engage in criminal activity. One scholar, Edward Crapsey $(1872$, p. 9) claimed in his book, The N ether Side of N ew York: Or the Vice, Crime and Poverty of the Great M etropolis, that the upper classes were indifferent to the suffering of the labouring population in tenements, which in part was responsible for the paralysis caused by crime in the city.

Leading criminological thought at the time viewed crime as a social phenomenon: 'Before individualistic theories came into vogue, explanations of crime were largely in terms of factors in the social environment' (Quinney 1970, pp. 46-7). Because of rapid changes experienced by particular geographic regions, including industrialisation, immigration, and the growth of cities, scholars turned their attention to social problems associated with these changes. For example, John Burt suggested in 1863 that crime was 'reproductive' and others argued that this stemmed from the 'habits of lower orders, bad education, idle servants, depraved morals or aquatic laborers, and ill-regulated public houses' (Quinney 1970, pp. 48-9). Additionally, mid-19th century American thought equated crime with 'sin, pauperism, and immorality' (Quinney 1970, p.50). The association of crime with disease was apparent in criminological thought during the era of consumption.

Perhaps the clearest example of this was the Chicago School of Human Ecology/ Criminology, which emerged largely as a result of environmental 
and social conditions which materialised at the turn of the century in Chicago, including extensive foreign immigration. Vold and Bernard (1986) described this immigration: 'Chicago was at that time a massive city of over 2 million; between 1860 and 1910 it had doubled in population every 10 years, with wave upon wave of immigrants' (p. 161). Such early sociological theorists argued that because of such conditions, urban areas were more crime-prone than rural areas (Foglio, Hakim, and Rengert 1986, p.xi). For example, Louis Wirth observed that life in cities creates societal anomie and individual alienation, conditions related to high crime rates and individual criminal behaviour.

Cities such as Chicago could be divided into sections such as the 'zone in transition' which was the oldest section of Chicago. This section was being invaded by business and industry. Residential housing there was deteriorated, and residents were generally poor immigrants. Tonnies, Simmel, and Maine viewed urban living in such conditions as essentially amoral and normless, which allowed crime to flourish (for example, see Berry 1981, pp. 9-15). Shaw and MacKay noted Chicago's stable delinquency areas over time, and commented that they were specialised for purposes of assimilating low income immigrants into the city. Even when the ethnic composition of the inner-city changed from German and Irish to Italian and Polish, high crime rates were consistently found closest to the centre of the city. When some groups became economically successful, they would move into the mainstream of American life, allowing new immigrant groups to move into the city's troubled zones. Those who were left behind would become socially isolated from middle-class norms and would simultaneously be exposed to conditions ripe for consumption infection.

Despite the fact that overall deaths from tuberculosis declined after the 1870s, the disease continued to spread especially among the immigrant poor. For example, the city-wide mortal ity rate in New York City by 1900 was 256 per 100,000, but in the poorest and most crowded districts, it hovered around 500 per 100,000 (Drolet and Lowell 1952). Of course, official crime rate statistics are historically located in similar conditions (Vold, Bernard, and Snipes 1997).

Knopf (1907, p. 2) stated that through 'ignorance or carelessness' immigrants spread 'their infectious sputum everywhere without any regard to the danger'. He also justified why preventive techniques were less effective among immigrants by stating that some of them, because of intemperance, and others because of privation, lacked the necessary resistance to fight off the bacilli.

The fast spread of tuberculosis among immigrants prompted some groups, such as the Progressives, to implement preventive mechanisms in an attempt to contain its growth. They defined the city as their laboratory and embarked on a campaign to investigate social conditions in the same way physicians investigated germs. The selection of the city as a laboratory was based on the fact that the city represented the site where undesirable behaviour occurred with the greatest amount of frequency. In the words of Anthony Platt (1966), the city 'symbolically embodied all the worst features of modern industrial life' (p. 17). 
The intent of the Progressives was to use data pertaining to poverty and disease in order to gather legislative support for crime prevention programmes as well as disease prevention programmes. Their findings supported the position that both tuberculosis and criminal behaviour flourished when families were crowded in 'dark interior rooms', had the poorest sanitary conditions, and also when they had 'the least nutritious diet and often spent time in the saloons and the beer halls' (Rothman 1994, p. 22). Thus, the CPTED techniques they adopted involved the remodeling of tenement housing, elimination of sweatshops, reduction of the hours of labour, abolition of child labour, establishment of municipal bathhouses, sterilisation of milk, purification of water, and the construction of playgrounds and parks which were considered to be the 'lungs of a great city' (Knopf 1907, p. 4). These environmental design strategies, which altered the environment in an attempt to prevent the spread of tuberculosis, were part of the grand Progressive programme which was intended to improve the quality of life and thereby eradicate all social ills, including crime.

The N ew York State Tenement H ouse Commission Report of 1900 (in De Forest and Veiller 1903) was the product of a close working relationship between physicians and settlement-house workers in their attempt to reform tenement houses. For 50 years reformers had labelled tenement houses as 'prolific sources of moral degradation and physical suffering' and proposed the design of model houses that would not allow the presence of foul odours and would reduce the propensity to immorality (Rothman 1994, p. 22). According to Veiller (1903), tenement-house living was not only correlated with crime, prostitution, and alcoholism, but also with tuberculosis.

The 1900 report followed in this tradition but energised the consumption/crime prevention (CPTED) campaign with new power and more specificity. This report was in reality a recommendation of CPTED strategies to be implemented in dwellings to modify the environment for the purpose of preventing the ills of society. Similar to the efforts of Shaw and McKay in their maps of Chicago, the authors of the report separated the city's districts with special markings to show the correlation between tenement houses and tuberculosis. According to Rothman (1994), poverty maps outlining the buildings in which families had applied for charity were superimposed on disease maps which identified with black dots, the buildings with a high number of cases of tuberculosis.

It may be clearly seen that most, if not all, of the strategies implemented with the aim of preventing the spread of tuberculosis also targeted the reduction of criminal behaviour, mostly because both were thought to stem from conditions of poverty. Charles Cooley, before the National Conference of Charities and Correction in 1896, referred to this interaction by stating that a criminal class depended as much upon social experiences and economic circumstances as upon the inheritance of biological traits. $\mathrm{He}$ stated that the 'criminal class' results from 'society's bad workmanship upon fairly good material'. Based on this belief, one of the early techniques implemented for the purpose of preventing the social evils associated with both consumptives and criminals was the geographic identification of their 
area of concentration. Thus, it can be argued that the creation of poverty maps represents an early attempt to identify regions where biological and social 'undesirables' were concentrated and where CPTED strategies could be implemented. These strategies were recommended by public health officials such as Biggs (1914, p. 14) who, as a result of his declaration that 'the danger of infection is largely diminished through ventilation', promoted the campaign to re-design living quarters in N ew York's tenement housing. Settlement-house club leaders also instructed members in a list of desirable behaviours including the opening of windows, letting in sunlight, preparing nutritious meals, and the discouragement of alcohol consumption.

However, the external environment was not the only subject of change. City and state officials in New York advocated a different CPTED strategy, one that affected the individual's internal condition. It was declared that persons with tuberculosis had to learn to follow rules of hygiene or they would face penalties. This measure was imposed on the sick with the intent of preventing further contamination of the general population. As noted by Robinson (1999), CPTED, as posited by Jeffery (1990), involves efforts geared toward changing both the external environment of the place and the internal environment of the offender. Recommendations related to personal hygiene during the era of consumption, thus, can be seen as CPTED measures under the Jeffery definition.

In addition, an educational campaign for the purpose of teaching lessons of hygiene was launched. A Johns Hopkins Medical School professor, William Welsh (1908, p. 22), stated that 'at least one-half of the existing sickness and mortality from tuberculosis could be prevented within the next two decades' if only the public had a 'clear understanding of the disease'. The educational campaign targeted immigrants, and in 1894 a pamphlet called 'Information for consumptives and those living with them' was published in various languages including German, Italian, and Yiddish (Rothman 1994). This pamphlet further illustrates the integration of consumption/ crime prevention strategies through environmental design.

The educational campaign grew in 1901 to a degree that the previously mentioned pamphlet had a distribution between 20,000 and 50,000 circulars in the tenement-house districts. According to Billings (1912), the number of languages in which the pamphlet was published increased to include Bohemian, Finnish, Polish, Slovak, Ruthenian, Swedish, Armenian, Spanish, and Chinese.

The preventive campaign did not rest with the distribution of pamphlets. Public health officials recognised the fact that a number of disease carriers were not being reached by this method. They felt that the first step towards preventing contagion was the identification of individuals who already had the disease. This was accomplished through the assistance of physicians as they became required to provide health officials with a list of names and addresses of all persons diagnosed with tuberculosis (Tobey 1947). Once the health department had the names of those with tuberculosis, they would send sanitation inspectors to the homes of individuals to begin a programme of education and supervision. This programme aimed at 
preventing the spread of the disease through the verbal instruction about the danger of infection and the care of the sputum. According to Rothman (1994), the inspector would explain to tuberculars the importance of sleeping alone, using their own utensils, expectorating into sputum cups, and coughing into napkins which would be disposed of by burning. Inspectors would also periodically examine tuberculars' family members to see if they were developing the disease. If they were, they would be sent for treatment immediately. If the family moved, they were tracked down and assigned to another inspector in their new city. Once the family had moved, inspectors would arrange for the premises to be tboroughly disinfected before new occupants moved in. If at any point of the preventive process the family refused to obey inspectors, formal procedures were to be initiated to take away the children and institutionalise the sick (Rothman 1994).

In the 1890s, Biggs (1894) was the first to promote coercive removal of children and institutionalisation of the sick for control of consumption as well as prevention of other social ills such as crime, poverty, and unemployment. In proposing policies for New York City, he argued that a tuberculosis registry was essential for the reduction of contagion. He insisted that, despite the fact that the U nited States was a democratic nation, it may be necessary to coercively isolate contaminating consumptives from the general population. Another official, Chapin (1894) affirmed Biggs's position by stating: 'our business, daily and hourly, leads us to the depletion of men's pockets and the restriction of their liberty. We cannot expect the thanks of those who feel themselves aggrieved' (p.12).

The New York Department of $\mathrm{H}$ ealth moved to introduce its public policies aimed at preventing contagion. In 1893, the department added tuberculosis to the list of diseases that could be transmitted. Physicians were mandated by law to notify the health department within ten days of the names and addresses of patients who had been diagnosed as tuberculars. According to Fox (1975, p. 49), four years later, the New York Department of $\mathrm{H}$ ealth made registration of tuberculosis compulsory. It was listed as a disease that was 'infectious' and 'communicable' with the potential of being 'dangerous to the public health'.

These governmental interventions were not implemented without resistance from those concerned with ethical implications. For instance, physicians became concerned with their physician-patient confidentiality, while others such as insurance company groups disregarded privacy-related concerns as they obtained copies of the tuberculosis registry. This registry assisted insurance companies in their decision-making processes to either grant or reject admissibility to their insurance plans. Sometimes, physicians gave wrong information pertaining to the cause of death for the purpose of securing benefits from the insurance companies (Rothman 1994).

H owever, despite these ethical concerns, preventive techniques not only remained in place in cities like New York, but were also implemented in cities where the tuberculosis problem was not great. By 1908, 84 cities required both registration of the sick and disinfection of lodgings. According to Rothman (1994), these procedures led to housing and employment discrimination. Landlords reportedly refused to rent to 
tuberculars while insurance companies invalidated policies that belonged to the sick. According to Kerr and Moll (1914), institutional discrimination under the justification of 'prevention' took place as states and municipalities passed laws prohibiting individuals with tuberculosis from working in dairies and bakeries or being hired as teachers in public schools. The fear of associating with those who had tuberculosis grew to such an extent that it prompted public health officials to exercise their police powers to influence legislation in an attempt to regulate interstate travel of the sick (Pottenger 1903). This preventive strategy of containment was suggested despite the fact its mere proposal created great controversy in some states, particularly California (Baur 1959).

In the 1880 s and 1890s, the practice of incarcerating repeated offenders with the intent of preventing them from committing further crimes, was extended by legislation to include anyone who persisted in not meeting the standards established by public health authorities (National Tuberculosis Association 1907). According to Rothman (1994), support for this measure grew among city and state officials as they realised the departments would use their authority against the vagrant, the poor, and the immigrant. Furthermore, Tobey (1947, p. 34) argued that the majority of city counsels and state legislatures considered the isolation of the tubercular as 'a valid exercise of the police power of the state'. This statement represents the gradual decrease of tolerance in regards to consumptives and the growth of the belief that the state forcibly enforce these isolation techniques. This movement towards a more aggressive preventive technique marked the beginning of drastic changes in the environment. The logic was that, through the isolation of some of the sick (who were at times regarded as potential criminals), the spread of other social ills would be prevented (including contagion and the opportunity to commit crimes).

This conviction was made clear by Dr Charles Ingraham (1896, p. 11), who urged the American Medical Association to promote a network of state hospitals in which indigent consumptives who lacked care in their hygienic habits, could be 'sentenced by health officials for a greater or lesser term, according to the seriousness and persistence of their offenses'. The fact that public officials used words such as 'sentence', 'offense', 'police', and 'inmate' when referring to issues surrounding tuberculars, depicts their similar views of criminals and tuberculars. This correlation prompted numerous officials to echo the previous initiative to confine the sick for the sake of preventing the spread of social illnesses.

William Welsh (1909), in an address to the National Association for the Study and Prevention of Tuberculosis, claimed that compulsory confinement was urgently needed. He stated that 'in dealing with patients who are a serious menace to the community, who cannot or will not be taught to take proper safeguards against the infection of their fellow-men, I think that the health authorities should be empowered to place them in proper institutions' (p. 24). At the same meeting, another physician, $\mathrm{Dr}$ John Billings Jr. (1894, p. 4), of the New York City's Department of Health, urged his colleagues to press without reservation towards the establishment of compulsory commitment laws in every state. $\mathrm{He}$ argued that, in this way 
'the consumptive tramp, roaming from one lodging house to another can now be removed to our institutions and kept under supervision'. Not only did physicians embrace this new initiative, but hospital administrators redesigned their facilities to accommodate tuberculars.

The N ew York City Department of $\mathrm{H}$ ealth in 1903 dedicated a pavilion of its contagious disease hospital, Riverside, to the tubercular. Consequently, hospitals began to adopt a new language pertaining to their handling of tuberculars. These began to be referred to as 'potential inmates'. The list enumerating the potential inmates grew rapidly. Usually, the 'public nuisance' was at the head of the list, closely followed by the tuberculars who had probably been discharged from regular hospitals as a result of being considered 'undesirable patients' (Rothman 1994). Others making part of the list included the homeless, dependent, dissolute, and friendless, along with others also considered to be dangerous to the community. According to Biggs (1914), it did not take long for hospitals such as Riverside to hold, in their assigned pavilions, a large number of potential inmates. This was due, in part, to the numerous referrals made by charity workers and other officials.

For instance, Mary Jones, a nurse, recommended to the New York Department of H ealth that John Standish (who was a dying consumptive) be removed from his apartment where he lived with his wife and five children. Nurse Jones's argument was that she had 'been visiting this case of tuberculosis for six weeks, paid eight visits', but had 'been unable to secure observance of those precautions necessary to prevent infection of others'. Therefore she 'recommended removal by force if necessary to Riverside H ospital' (Billings 1894, p. 21).

The fast growing pace of the isolation technique developed into the creation of the American sanatorium. These facilities were built with the intent of treating tuberculars while preventing contagion. It is important to keep in mind that the isolation of the sick in hospitals and the creation of the sanatorium were environmental design strategies aimed at controlling, (while using the pretence of 'prevention') those considered to be threats to the American way of life - the poor. Furthermore, these techniques were specifically designed to alter the environments where the poor lived. Thus, the idea behind the creation of the sanatorium was that social ills would disappear, through the removal of potential offenders from the changing environment. In fact, the sanatorium was unique in that it not only altered the existing environment but it also provided a new controlled environment where behaviour was modified at all times. Furthermore, like penitentiaries, sanatoriums incapacitated individuals considered to be pollutants by their ability to pollute the environment with social ills. The penitentiary and sanatorium used similar techniques to achieve their mutual goal of incapacitating society's undesirables in an attempt to contribute towards the effort of defending society. Similar to the sanatorium, the penitentiary has been described by Ansel (1987, p. 2) as having had the 'spirit of social defense'.

Furthermore, the moral basis by which the penitentiary and sanatorium operated by were similar. Under the Pennsylvania system, the Quakers believed that the penitentiary was a proper setting to improve the morality 
of the individual. Thus, by being incapacitated in these institutions the individual was encouraged to seek God's help in the physical and moral reformation.

The design of the sanatorium was first drafted by Edward Livingston Trudeau, who is also credited with having established the first sanatorium in the United States. Trudeau believed that the environment of the sanatorium had to encourage treatment procedures for patients. The main elements of such an environment had to be 'an invigorating climate, an open-air life, rest, coupled with the careful regulation of the daily habits and an abundant supply of nutritious food' (Rothman 1994, p. 18). It is clear that Trudeau was convinced that this regimen under a controlled environment would treat and possibly cure those who already had the disease, preventing its spread to the remainder of the population. Thus, the external environment was changed by the creation of the sanatorium. This facility was not only reactive in providing adequate treatment for consumptives but was also proactive in that it also aimed at isolating the 'target' population (that is, consumptives) for the purpose of preventing the spread of disease.

Despite the obvious disciplinary code of behaviour in sanatoriums, these facilities were designed to provide a unique environment for consumptives with the aim of avoiding the spread of infection from patient to patient. According to Rothman (1994), the 'cottages were well ventilated; partitions separated the individual sleeping spaces from the common sitting room, which, in turn, was in direct communication with the veranda on which the outdoor plan of treatment is carried out' (p. 18). In fact, each patient had a large air space to prevent contamination of buildings. In addition, the staff gave specific instructions about the proper disposal of expectoration. Trudeau installed spittoons throughout the facilities and frequently punished those who spitted indiscriminately in hopes of deterring such behaviour.

Within sanatoriums during the era of consumption, the daily schedule of each patient was specifically designed according to the stage of the disease. Daily moderate physical activity was almost always encouraged. However, vigorous exercise was al ways opposed. The common understanding was that in people with tuberculosis 'the organs and tissues have now an extra burden to bear. Exercise which in health would help to build up the normal body and increase resistance to disease, in this illness, when injudiciously carried out, leads to much harm, weakening the resisting powers and hastening the progress of the disease' (Rothman 1994, p. 19).

Today, since tuberculosis is on the increase again the United States, rates of tuberculosis are five times higher in prisons and jails than in the general population (Mueller 1998). Since most ventilation systems in most criminal justice facilities were not specifically designed to prevent the spread of tuberculosis, infected inmates can spread the disease easily when incarcerated. Higher rates of infection are found because of this, along with other factors, including: correctional facilities contain higher percentages of former substance abusers and HIV infected people; a high percentage of inmates did not take care of themselves while on the street and did not have access to legitimate health care prior to their incarceration. 
According to Mueller (1998, p. 134), today inmates are screened prior to their admission to a correctional facility, to protect staff and other inmates. When infected individuals are found, they are 'placed on a regimen of two to three drugs for six to twelve months' and are 'isolated in a negative air pressure system, which draws air out of the general prison facility but does not put air from the isolated area back into the general area of the prison'. So, treatment of tuberculars today is very similar to that during the era of consumption. The clientele is the same, as well, as prisons and jails are filled with poor people today.

Only the poor were granted admission in the sanatorium. This latter admission policy is of particular importance since it demonstrates the overall concern that existed at the time over the poor and the modifications of their environment. This concern, as explained earlier, was associated with the belief that the environment where the poor lived was responsible for the mass production of society's ills. The poor were also targeted in part because people in society did not believe they could be trusted to follow prescriptions without supervision (Rothman 1994). While the poor were seldom obligated to enrol in a sanatorium, they were 'strongly encouraged' by charitable organisations to seek admission in these institutions with the threat that, if they did not apply to be admitted, all charitable benefits would be terminated. Such coercive threats were consistent with those faced by criminal offenders locked up in penitentiaries of the time.

\section{Summary and Discussion}

Crime prevention through environmental design (CPTED) has been used in American society for centuries. This article focused on how CPTED strategies were used to prevent/ control the inter-related health problem of consumption and the social problem of criminal behaviour. These strategies included: recommendations from medical doctors and nurses; educational campaigns aimed at promoting lifestyle changes of infected and potentially infected individuals; travel and relocation efforts; altering inner-city conditions (for example, poverty, unemployment, tenement housing); and incarceration. Such efforts were sometimes aimed only at preventing either consumption or crime, but inevitably they helped alleviate both conditions. Since both social problems stemmed from similar environmental conditions, CPTED strategies aimed at preventing only one condition also helped alleviate the other.

That the CPTED policies aimed at preventing consumption during the era of consumption were aimed primarily at the poor and immigrant classes clarifies the similarity among CPTED practices aimed at preventing street crime, also perceived to be committed by poor groups. This article demonstrates that CPTED has historically been used to prevent ills associated with the lower classes.

Based on the foregoing illustration, it is apparent that biological, psychological, and sociological factors have always played a role in policies and practices of crime prevention through environmental design. However, in recent years, this role seems to have been minimised in the development 
of CPTED theories and research which focus only on social factors. While current CPTED theory and practice is grounded in incomplete models such as defensible space (Newman 1972), a broader understanding of CPTED can be achieved through an examination of historical time periods such as the era of consumption. Such an examination demonstrates that CPTED includes efforts aimed at eliminating or altering conditions not only of social environments, but also of internal physical environments of offenders and potential offenders. The truth is that CPTED has been utilised for centuries in America. One clear example of it was aimed at preventing the ills of crime and consumption during the 1800s and early 1900s.

Today, with the resurgence of tuberculosis in the U nited States - as noted earlier in the article, over 22,000 cases of full-blown tuberculosis are reported each year and an estimated ten to 15 million people are infected with the germ that causes tuberculosis - we have another opportunity to utilise CPTED strategies aimed at the internal environment of the sick and the external environment of the places in which they reside to alleviate this condition. Yet, because other conditions compound the spread of tuberculosis, medical efforts aimed to prevent its spread and to treat the ill are doomed to fail unless we also address the social issues which escalate the problem, including poverty, homelessness, substance abuse, a lack of access to medical care, and an increase in immigration from countries where tuberculosis is more widespread.

Likewise, with other medical conditions such as the spread of HIV and AIDS, any efforts aimed at their prevention are not likely to succeed unless CPTED strategies are designed to address factors within individuals ( that is, the internal environment) and also to alleviate social factors (that is, the external environment) which are related to their spread. For example, although 'several new compounds in a new class of drugs ( which) have been federally approved to treat HIV infection (and) when taken in combination with previously approved drugs ... reduce the level of HIV particles circulating in the blood ... to very low levels', 'A wide range of behavioral and biomedical strategies are needed to control the epidemic. No medical advance, by itself, can succeed unless it is accompanied by appropriate behaviour changes' (Centers for Disease Control and Prevention 1999).

A review of existing HIV/ AIDS prevention strategies by the U nited States Centers for Disease Control and Prevention (CDC) shows that they are in some ways similar to the methods used to control tuberculosis during the era of consumption. These include recommendations from medical doctors and nurses and educational campaigns aimed at promoting lifestyle changes of infected and potentially infected individuals. Educational campaigns have been launched, with the assistance of the CDC, in schools for children, in hospitals for health care workers, and at the street level for injection drug users. The CDC also promotes needle exchange programmes and encourages making clean needles available to injection drug users.

Also, many HIV/ AIDS infected persons are incarcerated (similar to the disproportionate confinement of persons with TB), thus, they have advocated condom use for inmates within US correctional facilities: 'Inmate populations probably represent the largest concentration of persons 
infected with, or at high risk for, HIV due to drug use and unsafe sexual behaviors' (CDC 1999). Given high recidivism rates in the US many infected inmates flow freely from US prisons back to their communities, logically infecting people in their neighbourhoods with whom they come into close physical contact. As noted by the CDC, the neighbourhoods most affected by this tragedy are 'communities that are already beset by poverty, drug use, violence, and disease'.

Given that minorities are disproportionately affected by poverty, the impact of HIV/AIDS on Hispanic and African American populations is great, as tuberculosis was highly concentrated among poor immigrants during the era of consumption. For example, between 1995 and 1996, HIV diagnoses increased in Hispanics by $10 \%$ in the 25 states with CDC surveillance systems, and the fastest growing rate of increase for reported AIDS cases is among African Americans. African Americans have the highest rate of AIDS infection, eight times that of whites, and $\mathrm{H}$ ispanics suffer from rates four times that of whites (CDC 1999). The CDC attributes such facts not to race and ethnicity alone, but rather to 'underlying social and economic conditions ( such as language or cultural diversity, higher rates of poverty and substance abuse ... limited access to health care ... and underemployment' ( $p .2$ ). Thus, CPTED strategies can only work if environmental changes occur, aimed both at internal and external correlates of HIV. A brief summary of how the HIV virus is spread sheds light on likely successful prevention activities.

According to the CDC (1999), HIV is spread by 'sexual contact with an infected person, by sharing needles and/ or syringes (primarily for drug injection) with someone who is infected, or less commonly ... through transfusions of infected blood or blood clotting factors' (p. 2) and when infants are exposed to an infected mother during or before birth or through breast-feeding. It can also be spread in health-care settings when workers are stuck with needles containing H IV-infected fluids ( or rarely) when they have direct bodily contact with HIV infected fluids. The HIV virus does not survive well in the external environment, but thrives in fluids such as blood, semen, vaginal fluid, and breast milk, and can also be found in smaller amounts in saliva, tears, and sweat.

HIV and TB are different in that HIV is not transmitted through the air according to the $C D C$, despite rumours to the contrary. This is why household transfers are so rare, because they require direct physical contact with an infected person (for example, sexual relations) or contact with infected material (for example, having one's mucous membranes exposed to infected blood). The CDC does not advise to limit contact with infected individuals; instead, they advise against sharing needles and personal instruments such as razors and toothbrushes and advise caution when handling materials exposed to the HIV virus unless properly disinfected. The CDC has also issued specific instructions for health care workers to generally follow in order to minimise risk of HIV infection. Additionally, the CDC provides advice about behaviours such as kissing and using protective devices such as condoms during sexual activity.

According to the CDC (1999): 'Wider use of medications for preventing 
tuberculosis ... has helped reduce the number of people with HIV who develop serious illness and die from AIDS' (p. 2). This may be because of the close connection between HIV and TB. TB is particularly dangerous for people infected with HIV, and worldwide, TB is the leading cause of death among people with HIV (CDC 1999). 'Because HIV infection so severely weakens the immune system, people dually infected with HIV and TB have a 100 times greater risk of developing active TB disease and becoming infectious compared to people not infected with HIV' (CDC 1999, p. 2). They are also more likely to die, as TB is the cause of death in one out of every three people with AIDS in the world. According to UNAIDS: 'onethird of the increase in TB cases over the last five years can be attributed to the HIV epidemic'.

Unfortunately, we have forgotten lessons learned from the successful CPTED strategies used during the era of consumption, hence the recent resurgence of TB infections. Fortunately, the fight against HIV/ AIDS has not suffered from a lack of Federal funding and widespread complacency. Perhaps in the wake of analysis such as these, investigators will begin to think more holistically when it comes to preventing illnesses and criminal behaviour. In these efforts, we should not lose sight, however, that al though diseases such as AIDS and TB are real, they also serve as 'metaphors' (Sontag 1995) for other statuses such as 'minority', 'poor', and populations perceived as threatening in other ways, including 'criminal'. Caution is in order to assure that measures aimed at alleviating AIDS and TB will not exclusively be used to call attention to the criminal behaviours by these groups, which could be potentially harmful to them through increased reliance on punitive measures such as incarceration.

\section{References}

Ansel, M. ( 1987) Social Defense: TheFuture of Penal Reform, Colorado: Fred B. Rothman and Co. Littleton.

Baur, J.E. (1959) The Health Seekers of Southern California, California: Huntington Library.

Bennett, T. and Wright, R. (1984) Burglars on Burglary: Prevention and the Offender, Vermont: Gower.

Berry, B.J.L. (1981) Comparative U rbanization, New York: Martin's Press.

Biggs, H.M. (1894) 'To rob consumption of its terrors', Forum, 16, 13.

Biggs, H.M. (1914) 'The municipal sanatorium at Otisville', in: New York City Department of $\mathrm{H}$ ealth. Reprint Series, 7, New York: New York City Department of Health.

Billings, J.S. (1894) Vital Statistics of New York City and Brooklyn Covering a Period of Six Years Ending M ay 31, 1890, Washington, DC: US Census Office.

Billings, J.S. Jr. (1912) The Registration and Sanitary Supervision of Pulmonary T ubercu losis in N ew York City (Monograph Series. No. 1), New York: New York City Department of $\mathrm{H}$ ealth.

Brace, L.C. (1880) The Dangerous Classes of N ew York and the Twenty Years' Work Among Them, New York, NY: Wgnkoop and Hallenbeck.

Brantingham, P. and Faust, F. (1976) 'A conceptual model of crime prevention', Crime and Delinquency, 7, 284-95.

Centers for Disease Control and Prevention (1999) Web site, located at: www.cdc.gov/ . 
Chapin, C.V. ( 1894) 'Pleasures and hopes of the health officer', in: E. Gorham (Ed.), Papers of Charles V. Chapin, M.D, New York: The Commonwealth Fund.

Clarke, R.V. (1995) 'CPTED and situational crime prevention in public housing' (paper presented to the Technical Assistance Workshop on CPTED organised by the US Department of Housing and U rban Development by SPARTA Consulting Corporation, unpublished).

Cooley, C.H . (1896) 'Nature vs. Nurture' in the M aking of Social Careers (Proceedings of the Conference of Charities and Corrections).

Crapsey, E. (1872) The N either Side of N ew York; or The Vice, Crimeand Poverty of the Great M etropolis, New York: Sheldon and Co.

Cross, B. (1958) H orace Bushnell: M inister to a Changing America, Chicago: University of Chicago Press.

Crowe, T. (1991) Crime Prevention Through Environmental Design: Applications of Architectural Design and Space Management Concepts, Boston: ButterworthHeinemann.

de Forest, R. and Veiller, L. (Eds.) (1903) The Tenement H ouse Problem, Vol. 1, New York: Macmillan.

Drolet, G.J. and Lowell, A.M. (1952) A H alf Century's Progress Against Tuberculosis in $\mathrm{N}$ ew Y ork City, 1900-1950, N ew York: Tuberculosis and H ealth Association.

Figlio, R., Hakim, S. and Rengert, G. (1986) M etropolitan Crime Patterns, New York: Criminal Justice Press.

Fox, D.M. (1975) 'Social policy and city politics: tuberculosis reporting in N ew York, 1889-1900', Bulletin of the History of M edicine, 49.

Ingraham, C.W. (1896) 'Control of tuberculosis from a strictly medico-legal standpoint', Journal of the American M edical Association, 27, 693.

Jeffery, C.R. (1971) Crime Prevention Through Environmental Design, California: Sage.

Jeffery, C.R. (1990) Criminology: An Interdisciplinary Approach, New Jersery: Prentice $\mathrm{H}$ all.

Kerr, J.S. and Moll, A.A. (1914) 'Communicable disease: an analysis of the laws and regulations for the control thereof in force in the United States', in: U.S. Public $\mathrm{H}$ ealth Service, Public $\mathrm{H}$ ealth Bulletin, 62, Washington, DC: United States Government Printing Office.

Knopf, A.S. (1907) Tuberculosis as a Disease of the Masses, and H ow to Combat It, New York: Fred Flori.

Lab, S. (1997) Crime Prevention: Approaches, Practices and Evaluations, Ohio: Anderson Publishing.

Leonard, C. (1879) Family H omes for Pauper and Dependent Children, Washington, DC: PACC.

Lloyd, C. (1965) The H ealth of Seamen, London: Navy Records Society.

Lombrosso, C. (1911) Crime: Its Causes and Remedies (trans. H .P. Horton), Boston: Little, Brown.

McCall, J.G. and Simmons, J.L. (1966) Identities and Interactions, New York: The Free Press.

Miller, P. (1956) Errand Into The Wildern ess, Cambridge, MA: H arvard U niversity Press.

Morrison, W.D. ( 1897) Juvenile Offen ders, New York, NY: Appleton.

Mueller, J. (1998) 'Locking up tuberculosis', Corrections T oday, October, 133-4.

National Tuberculosis Association (1907) A M anual of Tuberculosis L egislation, Atlantic City, NJ: National Tuberculosis Association.

Newman, O . (1972) Defen sible Space: Crime Prevention Through U rban Design, N ew York: Macmillan (published by Architectural Press, London, in 1973).

Platt, A. (1966) The Child Savers, Chicago: University of Chicago Press. 
Pottenger, F.M. (1903) 'Is another chapter in public Phthisiophobia about to be written?', California State Journal of M edicine, 1, 82.

Prudden, M.T. ( 1917) TheStory of The Bacteria and Their Relations to H ealth and Disease, New York: G.P. Putnam's Sons.

Quinney, R. (1970) The Problem of Crime, New York: Dodd, Mead and Co.

Robinson, M. (1999) 'The theoretical development of crime prevention through environmental design (CPTED)', in: W. Laufer and F. Adler (Eds.), The Criminology of Criminal Law, Advances in Criminological Theory, Vol. 8, New Brunswick, New Jersey: Transaction Publishers.

Rothman, S.M. (1994) Living in the Shadow of Death, Maryland: The Johns Hopkins University Press.

Sontag, S. (1995) IIIness as M etaphor \& AIDS \& its M etaphors, New York: Peter Smith.

Sweetser, W. (1836) Treatise on Con sumption, Boston: T.H. Carter.

Taylor, R.B. and Harrell, A.V. (1996) Physical Environment and Crime (National Institute of Justice Research Report), Washington, DC: US Department of Justice

The First Bicentennial Report of the Board of StateCommissioners of Public Charities of theState of Illinois (1871), Springfield, Illinois: Journal Printing Office.

The Second Bicentennial Report of the Board of State Commissioners of Public Charities of the State of Illinois (1871), Springfield, Illinois: Journal Printing Office.

Tobey, J.A. (1947) Public H ealth Law, New York: The Commonwealth Fund.

Veiller, L. (1903) Tenement House Reform in New York City, 1835-1900, New York: Macmillan.

Vold, G. and Bernard, T. (1986) Theoretical Crimin ology, N ew York: Oxford University Press.

Vold, G., Bernard, T. and Snipes, J. ( 1997) Theoretical Criminology, New York: Oxford University Press.

Watauga Democrat (1999) 'Spread of tuberculosis surprising', Watauga Democrat, February.

Welsh, W.H. (1908) What M ay be Expected From M ore Effective Application of Preventive M easures Against Tuberculosis (address delivered in Albany, NY, 27 January), Baltimore, MD: The Johns Hopkins U niversity.

Welsh, W.H. (1909) Compulsory Confinement (address given to the National Association for the Study and Prevention of Tuberculosis), New York, NY: National Association of the Study and Prevention of Tuberculosis.

Date submitted: March 99

Date accepted: September 99 